\title{
Diagnostic accuracy of MRI in local staging of rectal cancer, and determining the surgical resection margin status; retrospective study. The experience in Oman
}

\author{
AMA Al-Hadidi, , A Kamona, M Al Qubtan, J Al Kalbi, S Al-Tai, MS Al-Hanashi \\ From International Cancer Imaging Society (ICIS) 14th Annual Teaching Course \\ Heidelberg, Germany. 9-11 October 2014
}

\section{Aims and objectives}

To retrospectively review the accuracy of magnetic resonance (MR) imaging in preoperative staging of rectal cancer and to predict surgical circumferential resection margin status, with histopathologic results.

\section{Methods and materials}

MR images of 39 patients (15 underwent surgery without pre-operative treatment, while 24 had undergone pre-operative CRT or radiotherapy prior to MRI) with diagnosis of rectal cancer to evaluate tumour stage ( $\mathrm{T}$ stage), involvement of mesorectal fascia (MRF), and nodal metastasis ( $\mathrm{N}$ stage) were included in the study. Tumours were staged according to the TNM staging system (American Joint Committee on Cancer guidelines).

\section{Results}

We managed to correctly determine $\mathrm{T}$ stage in $86.6 \%$, and $70.8 \%$, correctly assess the status of MRF in $100 \%$, and $70.8 \%$, and correctly determine the $\mathrm{N}$ stage in $66.6 \%$, and $54.1 \%$, for the first and second group, respectively.

\section{Conclusion}

Main T staging errors contributed to desmoplastic reaction in the first group, or post-therapy changes in the second group, which also affected the MRF.

The limited accuracy of nodal size is likely to be related to the fact that $30 \%-50 \%$ of metastases in rectal cancer occur in nodes that are less than $5 \mathrm{~mm}$.

* Correspondence: aymenalhadidi@gmail.com

Oman Medical Specialty Board, Royal Hospital, Oman
MRI is the primary method for local staging of rectal cancer mainly due to high soft tissue resolution which makes it better in evaluating tumour extension, relation to adjacent pelvic organs, and also for the ability to assess the MRF. Results are highly dependent on the technique of the examination, which needs meticulous care and standardization.

Published: 9 October 2014

doi:10.1186/1470-7330-14-S1-P9

Cite this article as: Al-Hadidi et al.: Diagnostic accuracy of MRI in local staging of rectal cancer, and determining the surgical resection margin status; retrospective study. The experience in Oman. Cancer Imaging 2014 14(Suppl 1):P9.
Submit your next manuscript to BioMed Central and take full advantage of:

- Convenient online submission

- Thorough peer review

- No space constraints or color figure charges

- Immediate publication on acceptance

- Inclusion in PubMed, CAS, Scopus and Google Scholar

- Research which is freely available for redistribution
() Biomed Central 